\title{
Contribution of Indigenous Entrepreneurship Among Micro and Small Livestock Enterprises to Economic Development in Turkana County, Kenya
}

\author{
Wambui King'ong'o, \\ School of Business and Management studies, \\ Technical University of Kenya, Nairobi, Kenya \\ Martin Ogutu, Prof. \\ School of Business, University of Nairobi, GPO Nairobi, Kenya \\ Samuel Nyandemo, PhD \\ School of Economics, University of Nairobi, GPO Nairobi, Kenya
}

Doi:10.19044/esj.2020.v16n19p274 URL:http://dx.doi.org/10.19044/esj.2020.v16n19p274

\begin{abstract}
Entrepreneurs are required to have an entrepreneurial mind-set, values, attitudes and behaviour that enables opportunity recognition perceiving entrepreneurial activities as desirable and feasible. Micro and small livestock enterprises play a key role in the agricultural sector being the main economic sector of the IGAD countries. The goal of this study was to determine the contribution of indigenous livestock entrepreneurship to economic development in Turkana County. Endogenous growth, effectuation and entrepreneurial bricolage are anchoring theories. The study adopted positivist and phenomenology paradigms and cross sectional research design. The target population was all micro and small livestock enterprises, registered members of the Livestock Marketing Association in Turkana County; comprising of 598 livestock enterprises out of which a sample size of 339 MSEs was selected through proportionate stratified random sampling and simple random sampling techniques. Secondary and primary data were collected for analysis. The study purposely selected four firms from the survey method for case studies. Pilot was conducted and reliability and validity of the study instrument was evaluated. Descriptive and inferential analyses were done. ANOVA and simple linear regression analyses were evaluated. Significance was tested at 5\% level. The overall response rate was $78.2 \%$. The results revealed that indigenous entrepreneurship has a positive and significant effect on economic development in Turkana county, $(\mathrm{F}=129.4, \mathrm{P}=.000)$. The study concludes that indigenous entrepreneurship is important in determining economic development. The study suggests to business associations, financial institutions, NGOs and development agencies and Turkana County
\end{abstract}


government to facilitate and promote indigenous communities to pursue entrepreneurial activities.

Keywords: Indigenous entrepreneurship, economic development

\section{Introduction}

Empirical research posits that entrepreneurship contributes highly to economic development (Boufaden, 2013). Entrepreneurship is about initiating and managing an enterprise with a high degree of risk, creating value through combining resources in innovative ways (Greenfield, Strikton \& Aubey, 1979). Bird and Schjoedt (2009) state that entrepreneurship is the entrepreneurial dimension of innovation and risk, agreeing with Joseph Schumpeter (1883-1950), Jean-Baptiste Say (1767-1832) and Richard Cantillon (1680-1734), that enterprise growth is about bearing uncertainty, risk and innovation (Boutillier, 2013). Knight (1885-1972) depicts a direct relationship between the entrepreneur, ambiguity, risk and profit. Knight argues that ambiguity represents "defects of managerial knowledge" which ultimately accounts for profit and/or loss in idea implementation (Boutillier, 2013: 572). The entrepreneurial venture is a response to an opportunity in the market place (market dis-equilibrium) or a result of the best alternative (necessity entrepreneurship), (Picard, 2013). Necessity entrepreneurship is predominant in nations that exhibit low levels of economic progress.

Audretsch and Kelibach (2008) posit that an entrepreneurial community, where the entrepreneur does not represent a person, an occupation or a small business but an economic purpose have replaced the managed economy characterized by conformity, monotony, rigidity and homogeneity, based on large firms, mass production and taylorism without creativity. The 'relationship between entrepreneurship and firms' growth as well as economic growth has been the subject of a growing number of studies" (Boufaden, 2013: 623). Thus, the "interest in entrepreneurship as a domain of research has intensified" (Fisher, 2012: 1019). According to Bruton, Ahlstrom \& Obloj (2008) research has not been conducted to explain entrepreneurship impact to economic development. Rather, researchers are more concerned with the who, why and how of entrepreneurship; a phenomena described by Audretsch, Grilo \& Thurik (2007) as a 'scholarly disconnect' presenting opportunities for scholarly research.

The contribution of micro and small enterprises (MSEs) to economic development is widely being recognized by a majority of non-governmental organizations, emerging markets, bilateral and multilateral aid agencies. Among many Kenyan communities, Livestock plays an important economic and socio-cultural role. The Turkana practice nomadic pastoralism economy dating to 9000 years (Intermediate Technology Development Group (ITDG), 
2005). Indigenous populations are defined by International Labour Organization (ILO) (1991, as cited in Anderson, Peredo, Galbraith, Honig \& Dana, 2006) as:

Peoples in independent countries who are regarded as indigenous on account of their descent from the population which inhabited the country, or a geographical region to which the country belongs, at the time of conquest or colonization or the establishment of present state boundaries and who, irrespective of their legal status, retain some or all of their own social, economic, cultural and political institutions. (p.3)

Going by this definition, the peoples of Kenya are indigenous. Indigenous entrepreneurship is a form of enterprise where a peoples' culture and way of life and contemporary business concepts are successfully blend and are in harmony and positively contributing to the enterprise, providing income and other social cultural outcomes (Cahn, 2008). However, it does not stand in isolation from other forms of entrepreneurship.

Entrepreneurial initiatives for indigenous communities include identification of business opportunities, soliciting resources and starting businesses with the aim that these opportunities will satisfy their objectives, an endogenous approach to entrepreneurship adopted by other forms of entrepreneurship. In this study indigenous entrepreneurship is measured in terms of its characteristics including social and cultural embeddedness and innovation. As argued by Naude (2008: 18) "economic development is the process of structural transformation of an economy based on services and manufacturing". It encompasses the social, economic and political reorganization and re-orientation of the entire economy plus some aspects of economic growth through wealth creation. This study used New Human Development, Todaro and Smith (2012) to measure socioeconomic development, based on combining measures of education, health and income.

Entrepreneurship contribution to economic development is an area of study argued by a majority of researchers (Naude, 2008; Audretsch \& Kelibach, 2008). Naude (2013:1) noted that, "evidence on whether entrepreneurship matters for economic development is not straight forward; how entrepreneurship has been promoted and how it contributed to development in countries like China and the East Asian Tigers is still a matter of contention; and whether and why private-sector development initiatives may be effective is not well understood". Empirical studies using ILO, GEM and the World Bank databases, Naude (2013) have established that there lacks elaborate empirical results showing how entrepreneurship influences job creation and economic development. Not all entrepreneurs contribute to growth as well as being creative (Shane, 2009). The objective of this study was to determine the contribution of indigenous entrepreneurship among micro and small livestock enterprises to economic development in Turkana 
County. The study hypothesis is that, there is a significant influence of Indigenous entrepreneurship among micro and small livestock enterprises to economic development in Turkana County.

\section{Literature Review}

Endogenous growth, effectuation and entrepreneurial bricolage are anchoring theories of this study. Endogenous growth, a procedure of selfsustaining and increased revenue created largely through technological innovation Sachs (2007) underpins today's theoretical approaches to economic development. Innovation is a cumulative-returns-to-scale activity through addressing itself to the market and its marginal productivity, which is likely to increase with the amount of resources invested (Sachs, 2007). Customers and entrepreneurial prospects are presumed as existing in the endogenous growth logic. Entrepreneurship is voluntary, taking a linear process of "opportunity identification and evaluation (Shane, \& Venkataraman, 2000), planning (Delmar \& Shane, 2003), resource acquisition (Katz \& Gartner, 1988) and the deliberate exploitation of opportunities (Shane \& Venkataraman, 2000)" (Fisher, 2012: 1023). Effectuation theory advocates that the entrepreneur rely on what is within his / her control (understanding who they are and their social networks), apply the affordable loss principle (what one is willing to lose), avoiding calculating expected return on investment in risk assessment and establish leveraging strategic relations (building partnerships). This may include social networks, abilities and personal knowledge entrenched in an individual as well as human and physical resources at the organizational level (Fisher 2012). Sarasvathy (2008) advocates that the entrepreneur exploits contingencies rather than avoid them by accepting unanticipated occurrences and turn them into lucrative opportunities in uncertain and ambiguous environments.

Bricolage is about using resource in a different way from how it was initially purposed as argued by Baker and Nelson (2005) applying 'hands on' approach. Bricolage involves creating something from nothing by utilizing what is within one's control and thus, solving problems and uncovering opportunities. Bricolage is one of three options that an organization can choose when leaders are faced with penurious conditions. The possibilities are: seeking external resources, avoiding incoming problems through doing nothing or downsize or disband and enact bricolage by using available resources and applying resource combinations to solve problems and address opportunities (Fisher, 2012). Through the application of available resources the entrepreneur is able to influence physical, human or institutional capital innovatively. 


\section{Indigenous Entrepreneurship Contribution to Economic Development}

Indigenous entrepreneurship does not stand in isolation from the general field of entrepreneurship. Like other forms of entrepreneurship, it contributes to economic development through increasing the extent of the market, promoting specialization, creating employment, producing and commercializing high-quality innovations leading to productivity growth (Luiz, 2010; Boufaden, 2013). The role of entrepreneurship in economic development based on heightened development of the private enterprises has been an area of interest to policy makers. Public policy supporting entrepreneurship as a solution to joblessness is Africa's major focus, promoting indigenous entrepreneurship as opposed to the situation in colonial times where entrepreneurship was foreign dominated. Naude and Havenga (2007) argue that most of small enterprises in Africa stagnate at start-up, have a survivalist characteristic and very few participate in international trade demonstrating lack of expertise and finances. Luiz (2010) noted an abundance of small enterprises in Africa which instead of thriving are declining though convinced that Africa's growth will be anchored on the expansion of the extent and influence of entrepreneurial ventures. Brouwer, (1999) posit that liberalization should integrate specific local models for effective involvement in the international economic order. The Asian Newly Industrialized Countries (NICs) introduced their home-grown models with the states as independent actors, shaping development efforts and aligning the interest of Transnational Corporations to national interests and promoting indigenous entrepreneurship.

In the developing countries including fragile and failed states, entrepreneurship is being promoted to facilitate development. Among the industrialized countries, entrepreneurship has been described as key in maintaining and regaining worldwide economic competitive lead especially by the United States of America (Naude, 2008). Naude (2008) also stated that the Lisbon pronouncement in March 2000 unequivocally recognized enterprise development as a strategy for the European Union to become the most competitive economy by 2010. China's achievement of substantial poverty reduction is attributed to entrepreneurship. "Donors and international development agencies have turned to entrepreneurship to improve the effectiveness and sustainability of aid" (Naude, 2013:1). According to Naude (2008:1) "the role of entrepreneurs in the structural transformation of countries from low-income, primary-sector based societies into high-income service and technology-based societies" explains the contribution of private enterprise to economic development. Globally diverse forms of growth have been recorded ranging from "successful economic structural transformation" especially by the East Asian nations, "mixed-success transformations" by the states of the former Soviet Union, "rapid innovation episodes" "as in Finland, India, Ireland and the United States of America" (Naude 2008:3). 
According to Peretto (1999) endogenous growth theory, long-run structural change implies the shifting of an economy from capital accumulation development path to one motivated by knowledge accumulation that is the entrepreneurial aptitude. In the case that an economy produces low levels of intermediate products, consumer products sector uses primeval production techniques with low demand for refined new inputs (Naude, 2013). Potential entrepreneurs therefore lack incentives to start new organizations leading to the economy getting stuck in an underdevelopment trap, where primitive methods of production are used. Entrepreneurship and small business are important to economic development and growth strategy. Transforming scholarly work to economically utilizable information is not an impulsive and natural procedure (Braunerhjelm, Audretsch \& Carlsson, 2010). Studies done in Sweden and Japan indicating high rates of research and development (R\&D) lacks a positive relationship between research and development and gross domestic product (Boufaden, 2013). Where "faced with lack of explanation regarding the dynamics of fundamental knowledge transfer to the economic sphere", entrepreneurship is introduced "as the missing link in contemporary growth models" (Boufaden, 2013: 625). Entrepreneurs are involved in numerous enterprising undertakings among them opportunity identification, innovation and enterprise start-up, ensuring information transformation into economically beneficial and recoverable knowledge.

The endogenous growth model has been boosted by the introduction of entrepreneurial capital to explain differences in economic performance. The presence of determinants of entrepreneurship creates entrepreneurial capital, Audretsch and Kelibach (2008) which positively impacts growth dynamics. Determinants of entrepreneurship may include availability of trained workforce, dealers, information, institutions of higher learning, employment associations, indigenous enterprise groups, consultancy firms, marketing research firms, customer care and venture capital organizations; facilitating social relationships through networks. They are crucial in providing networks, monetary and technical assistance, facilitating local knowledge and a favourable entrepreneurial environment increasing business start-ups. According to Luiz (2010) entrepreneurship results from the growth of institutions which encourage enterprising activities consequently fueling economic development. Enforcement laws should be in place to control activities of the indigenous firms and the new entrants, though Luiz (2010) highlights the destructive consequences of excessive business laws and ineffective property rights policies in emerging nations. It has been noted that "many developing countries are sitting on top of enormous wealth, both physical and human, which they are not tapping into because of unsuitable" institutional environments (Luiz, 2010: 76). 
Boufaden (2013) explained exemplary economic enactment in Silicon Valley as attributed to the city's opulent bequest in entrepreneurial capital. Entrepreneurship is a factor of production in the convectional Cobb Douglas productivity function, one of the components contributing to economic development including knowledge, physical and human capital. Entrepreneurial capital therefore is a necessary determining factor for development (Audretsch \& Kelibach, 2008; Braunerhjelm et al., 2010). The UNDP, (2004) commission on the private sector and development advocated for business 'ecosystems' and networks providing a catalyst to local companies and entrepreneurs rather than acting as predators. The extent to which the indigenous people have developed entrepreneurship contributing to economic development in Turkana County is the focus of this study. Braunerhjelm et al. (2010) and Audretsch and Kelibach (2008) indicate causal relations between entrepreneurship and innovation and growth at regional levels.

Study results using ILO, GEM and the World Bank databases found that there seems to be a U-shaped correlation between entrepreneurship and individual nation's economic growth measured in GDP per capita (Naude, 2010b). These results imply high levels of entrepreneurship in developing nations compared to the newly industrialized nations (Wennekers, Van Stel, Thurik \& Reynolds, 2005). This means that entrepreneurs in developing countries exhibit less innovation and therefore are mostly necessity driven. High gross domestic product in middle income countries may be a consequence of more innovative entrepreneurial activities. Globally, indigenous communities have existed in exclusive settlements portraying very unique characteristics and practice indigenous entrepreneurship. The Aboriginal community of Australia form coalitions and mergers between them and with non-Aborigine allies creating and managing competitive enterprises, which compete successfully in the international markets (Anderson, Kayseas, Dana \& Hindle, 2004). Indigenous entrepreneurship entrenched in selfdetermination is the key to achieving prosperity (Anderson et al., 2004). Andean indigenous peoples of the Andes achieve growth grounded on communal activities, community resources and beliefs by means of 'Community-Based Enterprises'. The community acts in corporate both as a corporation and entrepreneur pursuing community's communal well-being (Peredo, 2001). Community based entrepreneurship is normally entrenched in societal cultural underpinnings and natural and informal institutions.

\section{Conceptual Framework}

The framework presented in Figure 1 shows the relationship between indigenous entrepreneurship and economic development configured out of the researchers' perception of study variable relationships. It illustrates 
indigenous entrepreneurship configured as independent variable, positively contributing to economic development configured as the dependent variable.

\begin{tabular}{|c|c|c|}
\hline $\begin{array}{l}\text { Indigenous entrepreneurship } \\
\text { - Social embeddedness } \\
\text { - Cultural embeddedness } \\
\text { - Innovation }\end{array}$ & H1 & $\begin{array}{l}\text { Economic Development } \\
\text { - Knowledge and skill level- Education } \\
\text { - Income / Wealth } \\
\text { - Health }\end{array}$ \\
\hline $\begin{array}{l}\text { INDEPENDENT } \\
\text { VARIABLE }\end{array}$ & & $\begin{array}{l}\text { DEPENDENT } \\
\text { VARIABLE }\end{array}$ \\
\hline
\end{tabular}

Figure 1: Conceptual Model

\section{Research Methodology}

This study adopts both the positivism and phenomenology philosophical orientation. Bryman and Bell, (2007) observed that reality is subjective and multiple hence only understood by examining the perceptions of selected case studies combining quantitative and qualitative research in this study. Cross-sectional design which entails qualitative or quantitative data collection linking two or more variables amongst two or more cases at a single point in time, which are then examined to detect patterns of association was used (Bryman, 2004). The study target population was all micro and small livestock businesses, registered members of the Livestock Marketing Associations (LMAs) under the County Livestock Marketing Council in Turkana County. A list comprising of 598 livestock enterprises availed from the County Livestock Marketing Council as at December, 2018 formed the population of this study. Proportionate stratified random sampling technique was used. The businesses were proportionately selected giving them all a near equal chance. The strata were the four main livestock markets ITDG (2005), that is Lokichoggio registering 67 MSEs, Kakuma had 56 MSEs, Lokichar 55 MSEs and Lodwar had 420 registered MSEs. Determining adequate sample size for each stratum amongst a population of 598 micro and small livestock businesses, this research adopted (Frankfort-Nachmias \& Nachmias, 1996) formula presented as follows:

$$
n^{1}=\frac{n}{1+\frac{n}{N}}
$$

Where $\mathrm{N}=$ size of population, $\mathrm{n}=$ estimated size of sample and $\mathrm{n}^{1}=$ optimal sample size

This formula was applied on the population to arrive at the sample size of 339 MSEs; 38 MSEs from Lokichoggio, Kakuma had 32 MSEs, Lokichar had 31 MSEs and 238 MSEs from Lodwar. Primary and secondary data were collected for analysis. Published sources of secondary data were used including economic surveys, County integrated reports and international agencies' reports relating to study variables. The questionnaires were 
administered to the owners or senior managers of the 339 micro and small livestock businesses in the sample. The study targeted the owners or senior managers (high ranking respondents) as the point of inquiry for their good prospects to provide required and accurate information on study variables (Kumar, 2005). This study purposely selected four firms from the survey method for case studies one each from Kakuma, Lokichoggio, Lokichar and Lodwar.

Descriptive statistics were used to analyze basic information about the data. Configuration variables were tested for linear relationships using Spearman's correlation coefficients. ANOVA, a statistical test for significance of the differences between the mean scores of more than two groups was used. Before testing the hypothesis, the study subjected the model to tests of statistical assumptions including normality, linearity, heteroscendasticity and multicollinearity. To test the hypothesis, simple linear regression analysis was computed. Statistical significance was computed and a P-value smaller than the recommended level of 0.05 was considered to be of significance. Information obtained from the four case studies was analyzed by way of focus group discussions and thematic conceptual content analysis. The findings obtained from the cases were compared (triangulation) with results from the survey data. Cronbach's alpha $\alpha$, the coefficient of reliability was computed using Stata programme to determine reliability of the research instrument. Each of the variables in the model was tested for reliability also using Cronbach's alpha coefficient $\alpha$, as shown in Table 1.

Table 1: Reliability Test

\begin{tabular}{crr}
\hline Variable & Number of items & Cronbach's alpha \\
\hline Indigenous Entrepreneurship & 22 & 0.9809 \\
Economic Development & 11 & 0.9576 \\
\hline
\end{tabular}

Source: Primary Data, (2019)

Table 1 shows that indigenous entrepreneurship had the highest Cronbach's Alpha Coefficient of 0.9809 and economic development had a Cronbach's Alpha Coefficient of 0.9576. These values were above 0.7 and therefore acceptable (Bryman \& Crammer 1997). To enhance the reliability of the questionnaire, a pilot study was conducted using random selection of $10 \%$ owners or senior firm managers and Cronbach's Alpha Coefficient calculated to assess the device's consistency. For this study a panel of experts was used to ensure that investigative questions guiding the study provide the required content and to ensure that the area under study is adequately sampled to limit expert bias. Discriminant validity measured whether concepts that are purported to be unrelated are actually unrelated. Panels of experts comprising university academicians (economists and entrepreneurship) participated in discussions on research findings and recommendations to establish practical 
areas of interventions in policy and or implementation of suggestions to identified beneficiaries. Criterion-related validity was used to predict by correlating test results with another criterion of interest which was demonstrated by results of hypothesis testing.

\section{Study Results}

This study focused on the contribution of micro and small livestock enterprises to economic development in Turkana County. Turkana way of life is highly communal and the perception of this study was that livestock entrepreneurs borrow start-up capital from their social friends and relatives but this study results indicated only 7.55 percent thus leaning on personal savings (90.57 percent) as source of start-up capital. Among the Turkana it was common for young boys to be given livestock by their relatives but they were meant to be kept and enlarge their herd but not for sale. Social embeddedness, Cultural embeddedness and Innovation are factors of indigenous entrepreneurship that were analyzed in order to determine the contribution of indigenous entrepreneurship among micro and small livestock enterprises to economic development in Turkana County. 5-point Likert type scale was used to evaluate the responses. The respondents were asked to indicate the extent of agreement with each of Indigenous Entrepreneurship (IE) statements, where (1. Not at all 2. Little extent 3. Moderate extent 4. Great extent 5. Very great extent).

In order to measure the influence of social embeddedness as one of the factors of indigenous entrepreneurship to economic development eleven statements were formulated and analyzed. As demonstrated in Table 2, it was established to a great extent that it was easy for the respondents to borrow money from friends (Mean=3.77, $\mathrm{SD}=0.95, \mathrm{CV}=25.13$ ). On the other hand, most of the respondents to a little extent agreed that the collateral for the credit obtained in business was provided by wealthy friends and relatives (Mean=2.22, $\mathrm{SD}=0.88, \mathrm{CV}=39.71$ ). For the case of Cultural embeddedness, eight parameters were observed as shown in Table 2. From the results, the respondents to a great extent agreed to having access to natural resources (land, livestock and labour) for business through kinship systems (Mean=3.63, $\mathrm{SD}=1.07, \mathrm{CV}=29.35)$. In addition, livestock enterprises were collectively organized as respondents agreed to a moderate extent (Mean=2.89, SD=1.31, $\mathrm{CV}=45.36$ ). Additionally, innovation had its share as a factor of indigenous entrepreneurship as shown in Table 2. The results showed that the respondents to a moderate extent agreed that their businesses have a trademark that distinguished their goods from their competitors (Mean=3.29, SD=.1.20, $\mathrm{CV}=36.61$ ) while other respondents to a great extent agreed that their businesses possessed business information that they kept secret which gave them an advantage over their competitors (Mean=3.63, $\mathrm{SD}=1.01, \mathrm{CV}=27.80$ ). 
Table 2: Indigenous Entrepreneurship

\section{Indigenous Entrepreneurship \\ Social embeddedness \\ This business aims to promote community} based economic development rather than strictly individual initiative

It is easy to borrow money from my friends The collateral for the credit obtained in our business was provided by wealthy friends and relatives

Relationship amongst families and friends provide financial gifts for start-up and working capital

I have a network of individuals who I trust to bring information regarding the business There is high level of trust as a business practice in the livestock sector

We benefit from the social network of other small businesses e.g. where a number of businesses pool resources together in order to reach a larger market area.

High degrees of personalized trust have locked Turkana County into closed, localized, cohesive community isolating them from opening up to wider perspectives of development

There exist multi-ethnic tolerance (bonding ties) between the Turkana and the Samburu/ Pokot/ Somali/ and Elgeyo Marakwet

Bilateral relations between the Turkana and Uganda/ Ethiopia/ and Southern Sudan are strong

We have a strong degree of cohesion and at the event of disruption we rebuild our businesses on traditional and culturally grounded foundation

\section{Average}

\section{Cultural Embeddedness}

Our culture shapes business strategies and goals

Our culture sets limits involving enterprise relations with the wider community

Our common culture and values are an important source of trust, a level ground for personal contacts used in business.

Livestock enterprises are collectively organized.

Business benefits goes beyond the individual providing multiple outcomes for groups of people
Mean

STD

CV

Skewness

Kurtosis
3.4302

1.1264

$3.7698 \quad 0.9474$

$2.2212 \quad 0.882$

$2.4170 \quad 1.0556$

$3.2604 \quad 1.2778$

$3.3245 \quad 1.1080$

$3.3811 \quad 1.0810$

$3.4151-1.1321$

$3.5208 \quad 1.1115$

$3.2104 \quad 1.0877$

$3.2981 \quad 1.2393$

$3.4453 \quad 1.0650$

$3.1811 \quad 1.0963$

2.8943

1.3129

3.5811
$3.3132 \quad 1.1231$
$-0.2639$

2.2816

32.8379

25.1313

$-0.2237$

2.3067

$-0.1998$

2.1797

39.7083

$-0.1609$

43.6740

39.1910

$-0.2663$

1.9924

33.3274

$-0.2304$

2.3299

$-0.2055$

2.3300

31.9718

$-0.1683$

2.1812

34.3452

$-0.2518$

2.2923

33.1491

$-0.2037$

2.2456

33.8980

$$
-0.2679
$$

2.3962

31.5691

$\mathbf{3 4 . 3 1 6 1}$

$-0.2220$

2.2662

37.5752

$-0.2326$

2.0534

30.9129

$-0.2244$

2.3539

$-0.0864$

2.2661

34.4632

45.3601

$-0.1165$

2.4086

$-0.2818$

2.4086
30.8636 
Where there are tensions between our way of life and business practices, I chose to tradeoff potential economic business success

retaining my social cultural capital e.g.

Family status and social identity

We stick to traditional roles in choosing business ideas

I have access to natural resources (land, livestock and labour) for business through kinship systems

\section{Average}

Innovation

Our business has dynamic capabilities that are difficult to copy

Our business has a trademark that distinguishes our goods from our competitors

Our business is in possession of business information that we keep secret to give us an advantage over our competitors

Average

\section{$3.3321 \quad 1.2198$}

\subsection{8}

36.6063

$-0.2781$

2.1430

$3.6302 \quad 1.0656$

$-0.2761$

2.3442

29.3531

\begin{tabular}{lllll}
3.3212 & 1.1641 & 35.0497 & -0.2132 & 2.1795 \\
\hline
\end{tabular}

The objective of this study was to determine the contribution of indigenous entrepreneurship among micro and small livestock enterprises to economic development in Turkana County. The study analyzed the variables under study as presented through hypothesis. The purpose of the study was to highlight the effect of indigenous entrepreneurship on economic development in Turkana County. The following hypothesis was put forward leading to testing of the relationship among predictor variables through simple linear regression model proposed by (Baron \& Kenny 1986).

H1: There is no relationship between indigenous entrepreneurship among micro and small livestock enterprises and economic development in Turkana County.

Table 3: Regression Results for Indigenous Entrepreneurship and Economic Development

\section{Model Summary}

\begin{tabular}{|c|c|c|c|c|c|c|}
\hline \multicolumn{2}{|c|}{ Model } & $\mathrm{R}$ & R Square & Adjusted R Square & \multicolumn{2}{|c|}{ Std. Error of the Estimate } \\
\hline & 1 & 884 & .771 & .715 & \multicolumn{2}{|c|}{.0687} \\
\hline \multicolumn{7}{|c|}{ Analysis of Variance (ANOVA) } \\
\hline & Model & Sun & quares $\quad \mathrm{df}$ & Mean Square & $\mathrm{F}$ & Sig. \\
\hline \multirow[t]{2}{*}{1} & Regression & & 12 & 423.12 & 129.39 & .000 \\
\hline & Residual & & 264 & 3.27 & & \\
\hline
\end{tabular}




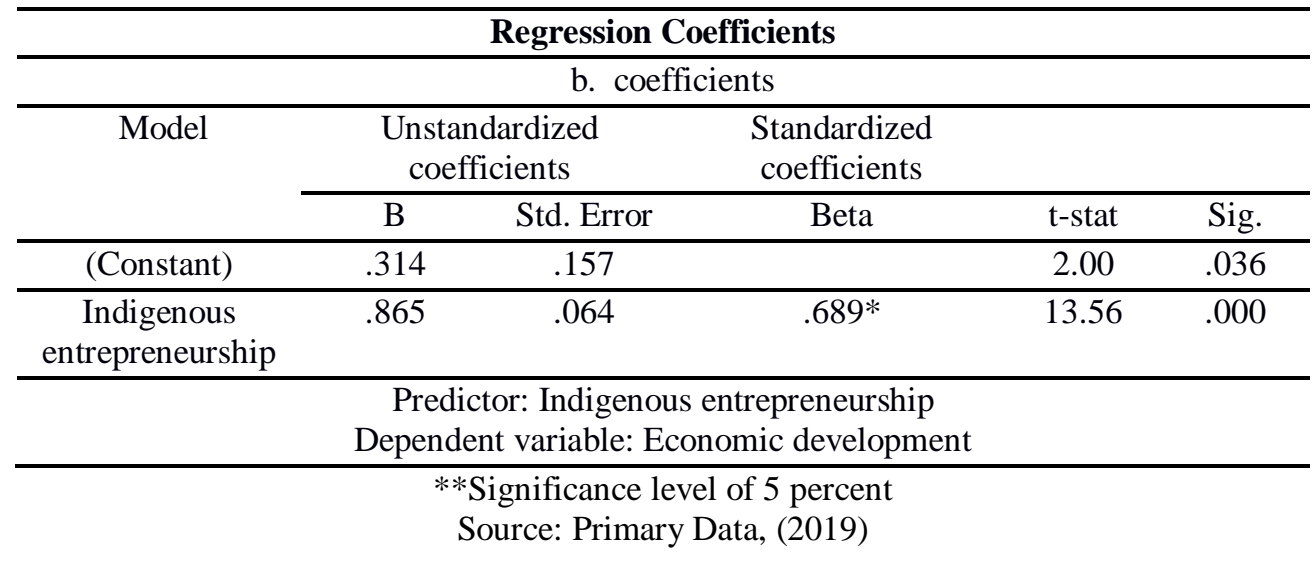

The study used coefficient of determination to evaluate the model fit. The adjusted $\mathrm{R}^{2}$, also called the coefficient of determinations, is the percent of the variance in the dependent explained uniquely or jointly by the independent variable. Table 3 shows that the model had an average adjusted coefficient of determination $\left(\mathrm{R}^{2}\right)$ of 0.771 which implied that $77.1 \%$ of the variations in economic development are explained by changes in indigenous entrepreneurship among micro and small livestock enterprises in Turkana County. The study thus concludes that estimation of the proposed model could proceed and that estimates are not biased. The study further tested the significance of the model by use of ANOVA technique presented in Table 3. From the ANOVA statistics, the study established the regression model had a significance level of $0.00 \%$ which is an indication that the data was ideal for making a conclusion on the population parameters as the value of significance (p-value) was less than 5\%. The calculated value was greater than the critical value $(\mathrm{F}=129.39$, and $\mathrm{p}$ value $=0.000)$, an indication that indigenous entrepreneurship has a significant effect on economic development. The significance value was less than 0.05 indicating that the model was significant.

To test the hypothesis, a simple linear regression analysis was conducted to determine the extent to which indigenous entrepreneurship influenced economic development. The composite index of the indigenous entrepreneurship dimensions and economic development was computed and a bivariate regression analysis performed to establish the influence of indigenous entrepreneurship and the results presented in Table 3. From the results, indigenous entrepreneurship and economic development were found to have a positive relationship. Holding indigenous entrepreneurship constant, economic development increases by 0.314 units. In particular, the result showed that for a unit rise in indigenous entrepreneurship, economic development increased significantly by 0.689 units holding other factors constant. The following was the estimated and significant model; 


\section{$\mathrm{ED}=0.314+0.689 \mathrm{IE}$}

The model above illustrates the extent to which significant factor that is indigenous entrepreneurship among micro and small livestock enterprises influence economic development in Turkana County. From the significance obtained from the p-value, the results imply that the null hypothesis of no significant effect is rejected.

\section{5.}

\section{Case Studies}

This section presents the analysis of the performance of businesses in the case studies. Businesses discussed are equally distributed among the four main (primary) markets of Lodwar, Kakuma, Lokichoggio and Lokichar. One MSE was purposely selected from each market. Similar approach was used by Orero (2008), who picked four informal Kenya-Tanzania cross border traders through purposive selection method. These cases were used as evidence to support thesis conceptual framework and study objective. The study aimed at determining the contribution of indigenous entrepreneurship among micro and small livestock enterprises to economic development in Turkana County. The actual business operations of the four firms triangulate both the literature review and data gathered through the questionnaire. Social embeddedness demonstrate social linkages and subjective relationships among performers of a commercial action. Trust cements these relationships. It was revealed that Mieebo Livestock traders' was socially embedded thus elements of trust, memberships of groups, relationships and networks were observed in the business operations of this entity. Mieebo livestock traders' is a member of Lodwar Livestock Marketing Association (LMA). The owner manager belongs to co-ethnic networks such as Kraals (arurum/ng'arurumio), and participate in external abiding traditional peace ceremony events.

Mieebo livestock traders' exploited effectively the benefits of social embeddedness reflected in trust, social networks and co-ethnic memberships promoting economic development through indigenous entrepreneurship. In his argument based on different spheres of trust John Mieebo (founder) explains the importance of bonding, bridging and linkages in social embeddedness. According to Hofstede (1980), diverse nations show preference of varied approaches towards enterprise growth, thus some people demonstrate an entrenched entrepreneurial behaviour while lacking among other people and influencing business operations. A community exhibit a particular way of life (national culture) (Hofstede, 2001) referring to attitudes, standards and opinions collectively acknowledged amongst members of a cluster. National culture impacts business as well as management. Indigenous peoples have affection to their original lands including the accompanying possessions, manifest traditional and socio-political organizations, their 
livelihoods are based on subsistence economy, local dialect occasionally dissimilar from the main dialect while the out-group identifies them as belonging to a distinctive ethnic cluster (World Bank, 2001). This is identified with Turkana impacting their business operations and economic development. Cultural embeddedness was rated strongly in the scale of priorities of Mieebo livestock traders'. It refers to how collective understanding shapes strategies and goals and sets limits to economic rationality involving enterprise relations with the wider community where economic activities are carried out. The owner manager demonstrated elements of cultural networks such as common culture and values which were a significant foundation to trust, a level ground to individual acquaintances as well as conducive economic linkages.

The Chief Executive Officer (CEO) of Nangorok livestock enterprise was asked to describe the level of trust as a business practice in their LMA and rated it very high. The enterprise through effective bonding and belonging to various social groups was legitimized attracting societal benefits such as gifts and favours. Nangorok livestock enterprise is a member of Kakuma LMA warranting direct assistance from the County Livestock Marketing Council (CLMC) and Kenya Livestock Marketing Council (KLMC). The members of this LMA shared a lot in terms of market information, provided credit facilities and partnerships. Nangorok Livestock enterprise rely on referrals from peer reference groups through word of mouth and phone calls for marketing its products. Trust builds long lasting and profitable interpersonal, organizational and institutional relationships. In addition to these Lokichoggio livestock traders' embraced hard work and experience. The founder invested much effort and time persuading youth warriors to abandon cattle rustling and start a livestock association because he believed that benefits of livestock trade can be realized in a group thereby founding Lokichoggio LMA. It was noted that the ownership coming from the same locality was therefore socially and culturally well placed to operate a livestock business in the area. Additionally the owner manager being a former youth warrior leader and due to his persuasive leadership skills, the members respected him so much, thus promoting social well-being. Therefore Lokichoggio livestock traders operations demonstrated social embeddedness in trust, relationships and networks and membership of social network groups as well as tribal groups.

Above all Long'acha livestock enterprise demonstrated the crucial role social networks played in business development. All cultural rites were supported by livestock, making this business culturally embedded. It was evident that Livestock cuts across the livelihood of all Turkana Community. For instance different traditional activities like music festivals attract people from different quarters hence promoting peace and business. This is in line with suggestions of (Audretsch, et al, 2007) who noted that the presence of determinants of entrepreneurship, created entrepreneurship capital which 
positively impacted growth dynamics. The cases discussed identified themselves with common values and culture where Turkana culture and way of life and business concepts blended and were in harmony and contributing to the enterprise, providing income and other social cultural outcomes. The cultural practice of valuing and respect for livestock is wide spread in Turkana County and embraced by owner managers and workers of these businesses, thus receiving income and prestige. The owner managers and employees are able to meet required social-cultural obligations of marriage, traditional ceremonies such as young men rite of passage "Espan" all attributed to their businesses. However, the four cases discussed had not embraced innovation hence had no record of any patent and registered trademark of products/services with relevant authorities such as Kenya Industrial Property Institute (KIPI), World Intellectual Property Office (WIPO) or African Regional Intellectual Property Office (ARIPO). The traders differentiated their livestock through traditional clan branding and use of distinct colours to label their livestock.

\section{Discussion of Results}

The findings from the estimated model revealed that indigenous entrepreneurship significantly influenced economic development positively. The study failed to reject the alternative hypothesis on the relationship between indigenous entrepreneurship and economic development. The implication is that micro and small livestock enterprises are sensitive to indigenous entrepreneurship as they contribute to economic development through increasing the extent of the market, promoting specialization, creating employment, producing and commercializing high-quality innovations leading to productivity growth as alluded by (Luiz, 2010; Boufaden, 2013). Indigenous entrepreneurship remains a critical factor in micro and small livestock enterprises. Local entrepreneurs contribute a lot in the structural transformation of an economy based on services and manufacturing. According to Gries \& Naude, (2010) it involves significant changes to methods of production, spearheaded by entrepreneurs who provide innovative inputs, permitting specialization and raising productivity and employment. The findings are in tandem with extant literature which suggests that social, cultural and innovation are primary determinants for growth; that innovative inputs, permits specialization and raises productivity and employment (Gries \& Naude, 2010). Quantitative analyses demonstrate a positive relationship between indigenous entrepreneurship and economic development indicating that micro and small livestock enterprises in Turkana County contribute to economic development. Case study results agree with the findings of the study. The cases discussed were socially and culturally embedded demonstrating elements of trust, memberships of groups, relationships and 
networks as well as showing a significant level of innovation through traditional methods of differentiating their products.

\section{Conclusions, Recommendations and Suggestions for Further Research}

Literature concurs that entrepreneurship is the engine of economic development. This study indicated that only 7.55 percent of respondents borrow start-up capital from their social friends and relatives, thus leaning on personal savings ( 90.57 percent) as source of start-up capital, though the Turkana way of life is highly communal. The relationship established based on the hypothesis reveal that indigenous entrepreneurship significantly impacts economic development. The study concluded that there is a statistically significant and positive relationship between indigenous entrepreneurship and economic development and that indigenous entrepreneurship is important in determining economic development. The null hypothesis of no significant effect of indigenous entrepreneurship on economic development in Turkana County was thus rejected. Scholars agree that micro and small livestock enterprises play an important economic and socio-cultural role amongst many Kenyan communities including the current study of Turkana County.

The relationship between indigenous entrepreneurship among micro and small livestock enterprises and economic development in Turkana County was established. This augured well with the propositions of endogenous growth theory where individuals were perceived to take entrepreneurial action through identifying gaps where the demand for a product/service exceeds supply, therefore identifying an opportunity and validating its worth for exploitation. The fact that entrepreneurship is a linear process of "discovery, evaluation and exploitation of opportunities given that it is voluntary, is confirmed in this study. Under entrepreneurial bricolage theory, it was argued that the entrepreneur enacts bricolage, tests and counter limitations shaping the relationship between bricolage activities and growth of their businesses. This is relevant to entrepreneurs operating in "environments that present new challenges without providing new resources" (penurious environments). This study concludes that indigenous entrepreneurship actually exists, and as other studies established, there are people defined as indigenous people. The study suggests that indigenous entrepreneurship is an area that needs to be critically enhanced in order to improve economic development across the board in Turkana County.

Economic development in indigenous communities must be built on entrepreneurial enterprises or activities of these people and their products. The County government of Turkana is supposed to have a paradigm shift to institutionalize indigenous entrepreneurship to foster self- regeneration and 
economic development. Actually, the study supports other empirical findings that its time both levels of governments enhance their environmental factors to lower uncertainty, raise indigenous entrepreneurs to participate at the global economy, attracting private sector development, creating employment, increased exports and finally spur economic development through huge investments in health, education while impacting wealth levels. The study was limited to responses of MSEs located along the central transport axis across Turkana County. Considering that the total number of livestock enterprises operating in Turkana County is dynamic and geographically diverse, some businesses were in dangerous locations and not easily accessible prompting delays in obtaining data. This study should be replicated in among micro and small livestock enterprises operating in Counties outside Turkana but with similar characteristics such as Samburu, Marsabit, Wajir and Garrisa to establish if similar findings could be achieved.

\section{References:}

1. Anderson, R. B., Kayseas, B., Dana, L. P. \& Hindle, K. (2004). Indigenous land claims and economic development: The Canadian experience. American Indian quarterly, Vol. 28, No. (3\&4), 634-648.

2. Anderson, R. W., Peredo, A. M., Galbraith, C., Honig, B. \& Dana, L. P. (2006). Toward a theory of indigenous entrepreneurship. International Journal of Entrepreneurship and Small Business, 1 (1), $1-20$.

3. Audretsch, D. B., Grilo, I. \& Thurik, R. (2007). Explaining entrepreneurship and the role of policy: A framework. Handbook of research on entrepreneurship policy (pp. 1-17).

4. Audretsch, A. D., \& Kelibach, M. (2008). Resolving the knowledge paradox: Knowledge-spill over entrepreneurship and economic growth. Research Policy, 37 (10), 1697-1705.

5. Baker, T. A., \& Nelson, R. E. (2005). Creating something from nothng: Resource construction through entrepreneurial bricolage. Administrative Science Quartely, 50, 329-366.

6. Bird, B. \& Schjoedt, L. (2009). Entrepreneurial behavior: It nature, scope, recent research, and agenda for future research. In A. L. Carsrud \& M. Brannback (Eds.), Understanding the entrepreneurial mind (international studies in entrepreneurship), 327-358. New York: Springer

7. Boufaden, N. (2013). Entrepreneurship and business growth. In E. G. Carayannis (Ed.), Encyclopedia of creativity, invention, innovation and entrepreneurship, (pp. 568-575). doi:10.1007/978-1-4614-3858-8 
8. Boutillier, S. (2013). Entrepreneur and economists. In E. G. Carayannis (Ed.), Encyclopedia of creativity, invention, innovation and entrepreneurship, (pp. 623-628). doi:10.1007/978-1-4614-3858-8

9. Braunerhjelm, P. Acs, Z. J., Audretsch, B. \& Carlsson, B. (2010). The missing link: Knowledge diffusion and entrepreneurship in endogenous growth. Small Business Economics, 34, 105-125.

10. Brouwer, J. (1999). Modern and indigenous perceptions in small enterprises. Economic and political weekly, 34 (48), 152-156

11. Bryman, A., \& Cramer, D. (1997). Quantitative data analysis with SPSS for windows: A guide for Social Scientists. London, Routledge.

12. Cahn, M. (2008). Indigenous entrepreneurship, culture and microenterprise in the Pacific Islands: Case studies from Samoa.

13. Fisher, G. (2012). Effectuation, causation and bricolage: A behavioural comparison of emerging theories in entrepreneurship research. Entrepreneurship Theory and practice, 36 (5), 1019-1051.

14. Frankfort-Nachmias, C., \& Nachmias, D. (1996). Research methods in the social sciences $\left(5^{\text {th }}\right.$ Ed.). London, Great Britain: St Martins Press.

15. Greenfield, S. M., Strikton, A. \& Aubey, R. T (Eds.). (1979). Entrepreneurs in cultural context. Journal of Social History, 15 (1), 147-149.

16. Gries, T., \& Naude, W. A. (2010). Entrepreneurship and structural economic transformation. Small Business economics journal, 34 (1), 13-29.

17. Hofstede, G. (1980). Culture's consequences: International differences in work- related values. Beverly Hills, CA: Sage publications.

18. Hofstede, G. (2001). Culture's consequences: comparing values, behaviors, institutions, and organizations across nations ( $\left.2^{\text {nd }} \mathrm{Ed}.\right)$. Thousand Oaks, CA: Sage Publications.

19. Intermediate Technology Development Group- ITDG. (2005). Livestock Market Acess Initiative: Pre-assessment and feasibility analysis, North Eastern Turkana. Nairobi, Kenya.

20. Kumar, R. (2005). Research methodology: A step-by-step guide for beginners ( $2^{\text {nd }}$ Ed.). Singapore: Pearson Education.

21. Luiz, J. M. (2010). Economic perspectives of entrepreneurship. In B. Urban, (Ed.), Frontiers in Entrepreneurship, (pp. 63-84). Berlin, Germany: Springer-Verlag. Doi:10.1007/978-3-642-04502-8

22. Naude, W. (2008). Entrepreneurship in economic development: Research Paper No.2008/20. Retrieved from https://pdfs.semanticscholar.org/83dc/0215aba844381f2ee825490513 9abcfaba97.pdf 
23. Naude, W. A. (2010b). 'Entrepreneurship is not a binding constraint on growth and development in the poorest countries'. World Development, 39(1), 33-44.

24. Naude, W. (2013). Entrepreneurship and economic development: Theory, evidence and policy. Discussion Paper No.7507. Retrieved from http://ftp.iza.org/dp7507.pdf

25. Orero, R. A. (2008). Entrepreneurship and social capital: A study of informal cross-border trade between Kenya and Tanzania. (unpublished PhD Thesis) Nairobi: University of Nairobi, School of Business.

26. Peredo, A. M. (2001). 'Communal enterprises, sustainable development and the alleviation of poverty in rural Andean communities,' $\mathrm{PhD}$ thesis, University of Calgary.

27. Peretto, P. F. (1999). Industrial development, technological change, and long-run growth. Journal of Development Economics, 59, 389417.

28. Picard, F. (2013). Entrepreneurial opportunity. In E.G. Carayannis (Ed.), Encyclopedia of Creativity, Invention, Innovation, and Entrepreneurship, (615-619).

29. Sachs, J. D. (2000). Globalization and patterns of economic development. Weltwirtschaftliches Archiv, 136 (4), 579-600.

30. Sarasvathy, S. D. (2008). Effectuation: Elements of entrepreneurship expertise. New Horizons in Entrepreneurship Research. Cheltenham, UK: Edward Elgar.

31. Shane, S. \& Venkataraman, S. (2000). The promise of entrepreneurship as a field of research. Academy of Management Review, 25(1), 217-226.

32. Todaro, M. P., \& Smith, S. C. (2012). Economic development $\left(11^{\text {th }}\right.$ Ed.). Addison-Wesley, Boston: Pearson Education.

33. United Nations Development Programme Commision on the Private Sector and Development. (2004). Unleashing entrepreneurship: Making business work for the poor. Retrieved from https://ycsg.yale.edu/sites/default/files/.files/unleashing_entrepreneur ship.pdf

34. Wennekers, S., Van Stel, A., Thurik, R. \& Reynolds, P. (2005). Nascent entrepreneurship and the level of economic development'. Small Business Economics, 24, 293-309.

35. World Bank, (2001). World development report 2000/2001: Attacking poverty. Retrieved from https://openknowledge.worldbank.org/.bitstream/handle/10986//1185 6/.World\%20development\%20report\%2020002001.pdf?sequence $=1 \&$ isAllowed $=\mathrm{y}$ 